\author{
Pawel Gala ${ }^{1}$
}

\title{
Roślinne zasoby genetyczne jako przedmiot praw własności intelektualnej
}

\section{Zagadnienia wstępne}

Przedmiotem niniejszego opracowania jest próba odpowiedzi na pytanie, czy roślinne zasoby genetyczne mogą stanowić przedmiot praw własności intelektualnej, a jeśli tak - to w oparciu o jakie regulacje prawne ochrona taka jest przyznawana i jaki jest jej zakres? Poszukując odpowiedzi na tak postawione pytanie, konieczne jest w pierwszej kolejności zdefiniowanie pojęć „własności intelektualnej” oraz „zasobów genetycznych”.

Pojęcie „własności intelektualnej” wywodzi się z doktryny prawa francuskiego, w której pojawiło się ono już na początku XVIII w. ${ }^{2}$ w wyniku wpływu na prawo stanowione koncepcji filozoficznych prawa natury. To właśnie koncepcjom prawa natury zawdzięczamy tezę, że własność przedmiotu należy do osoby, której wysiłek, zdolności i praca doprowadziły do jego powstania. Koncepcję tę W. Warburton rozszerzył na dobra niematerialne podnosząc, że człowiek jest właścicielem wytworu swojego umysłu³.

Współcześnie termin „własność intelektualna” został szeroko upowszechniony. Występuje w nazwie organizacji międzynarodowej - Światowej Organizacji Własności Intelektualnej ${ }^{4}$, a także w tytułach umów międzynarodowych ${ }^{5}$ oraz aktów prawa wtórnego Unii Europejskiej ${ }^{6}$. Mimo tej powszechności, brak jest w polskim prawie krajowym oraz $\mathrm{w}$ aktach prawa międzynarodowego jednolitej legalnej

$1 \quad$ Uniwersytet Śląski.

2 R. Skubisz, Własność przemysłowa w systemie prawa, (w:) System Prawa Prywatnego, Tom 14A, Prawo własności przemysłowej, R. Skubisz (red.), Warszawa 2012, C.H. Beck, s. 44.

3 V. Jänich, Geistiges Eigentum: eine Komplementärerscheinung zum Sacheigentum?, Mohr Siebeck 2002, s. 64.

$4 \quad$ Powołanej na podstawie art. 1 Konwencji o ustanowieniu Światowej Organizacji Własności Intelektualnej z dnia 14 lipca 1967 r. (Dz.U. z 1975 r., nr 9, poz. 49).

$5 \quad$ Np. załącznika 1C do Porozumienia ustanawiającego Światową Organizację Własności Intelektualnej - Aspekty Handlowe Własności Intelektualnej (TRIPS), Traktatu o własności intelektualnej w odniesieniu do układów scalonych - przyjętego w Waszyngtonie w dniu 26 maja 1989 r., czy też Konwencji Beneluksu w dziedzinie własności intelektualnej (znaki towarowe i wzory) podpisanej w Hadze w dniu 25 lutego 2005 r.

$6 \quad$ Np. Dyrektywy 2004/48/WE Parlamentu Europejskiego i Rady z dnia 29 kwietnia 2004 r. w sprawie egzekwowania praw własności intelektualnej (Dz. Urz. WE L 157 z 30.04.2004 r., s. 45-86), Dyrektywy Rady 92/100/WEG 
definicji pojęcia „,własności intelektualnej”. Jak podkreśla się w literaturze ${ }^{7}$, pojęciem „,własności intelektualnej” określa się zespół norm dotyczących dóbr intelektualnych, ale także nazywa się tak zespół praw podmiotowych dotyczących tych dóbr. Wskazuje się również, że prawa własności intelektualnej można zdefiniować jako monopole ustawowe przyznane przez państwo na określony czas w odniesieniu do pewnych tworów umysłu 8

W braku jednolitej, legalnej definicji pojęcia „własności intelektualnej” trudno także o ostro zarysowany zakres praw własności intelektualnej. Konwencja o ustanowieniu Światowej Organizacji Własności Intelektualnej, zgodnie z jej art. 2, obejmuje zakresem pojęcia „,własność intelektualna” prawa odnoszące się do: 1) dzieł literackich, artystycznych i naukowych, 2) interpretacji artystów interpretatorów oraz do wykonań artystów wykonawców, do fonogramów i do programów radiowych i telewizyjnych, 3) wynalazków we wszystkich dziedzinach działalności ludzkiej, 4) odkryć naukowych, 5) wzorów przemysłowych, 6) znaków towarowych i usługowych, jak również nazw handlowych i oznaczeń handlowych, 7) ochrony przed nieuczciwą konkurencją oraz 8) wszelkich innych praw dotyczących działalności intelektualnej w dziedzinie przemysłowej, naukowej, literackiej i artystycznej.

Porozumienie w sprawie Aspektów Handlowych Własności Intelektualnej (TRIPS) w art. 1 wskazuje, że pojęcie ,własność intelektualna” odnosi się do wszystkich kategorii własności intelektualnej, stanowiących przedmiot uregulowania sekcji 1-7 części II porozumienia, tj. do: 1) praw autorskich i pokrewnych, 2) znaków towarowych, 3) oznaczeń geograficznych, 4) wzorów przemysłowych, 5) patentów, 6) wzorów masek (topografii) układów scalonych oraz 7) informacji nieujawnionych.

Również na szczeblu Unii Europejskiej podjęto próbę oznaczenia zakresu pojęcia „własność intelektualna”. Dyrektywa 2004/48/WE Parlamentu Europejskiego i Rady z dnia 29 kwietnia 2004 r. w sprawie egzekwowania praw własności intelektualnej w art. 2 wskazała, że przewidziane niq procedury $i$ środki naprawcze stosuje się do wszelkich naruszeń praw wtasności intelektualnej określonych w prawie wspólnotowym i/lub prawie wewnętrznym zainteresowanego Państwa Członkowskiego. Celem sprecyzowania terminologii dyrektywy, Komisja Europejska wydała oświadczenie ${ }^{9}$, w którym stwierdziła, że w jej opinii zakresem dyrektywy objęte są co najmniej takie prawa własności intelektualnej, jak: 1) prawo autorskie, 2) prawa pokrewne z prawami autorskimi, 3) prawo sui generis twórców baz danych, 4) pra-

z dnia 19 listopada 1992 r. w sprawie najmu i użyczenia niektórych praw pokrewnych prawu autorskiemu w zakresie własności intelektualnej (Dz. Urz. WE L 346 z 27.11.1992 r., s. 61-66).

7 R. Skubisz, Własność przemysłowa..., op. cit., s. 44-45.

8 M. Blakeney, Trends in Intellectual Property Rights relating to genetic resources for food and agriculture, FAO 2011, Background Study Paper No 58, s. 8.

9 Oświadczenie Komisji dotyczące art. 2 Dyrektywy 2004/48/WE Parlamentu Europejskiego i Rady w sprawie egzekwowania praw własności intelektualnej (Dz. Urz. UE L 94, z dnia 13.04.2005 r., s. 37). 
wa twórcy topografii produktów półprzewodnikowych, 5) prawa ze znaku towarowego, 6) prawa ze wzoru, 7) prawa z patentu, włącznie z prawami wynikającymi z dodatkowych świadectw ochronnych, 8) oznaczenia geograficzne, 9) prawa ze wzoru użytkowego, 10) prawa wynikające z systemu ochrony odmian roślin, 11) nazwy handlowe, jeżeli są one chronione jako wyłączne prawa własnościowe w danym prawie krajowym.

W ramach zakreślanego w ten sposób pojęcia „,praw własności intelektualnej” doktryna wyróżnia zazwyczaj dwie podstawowe kategorie: 1) własność przemysłową oraz 2) prawa autorskie i prawa pokrewne ${ }^{10}$. Jak podkreśla się w piśmiennictwie ${ }^{11}$, wyrazem rozdzielenia własności intelektualnej na prawo własności przemysłowej i prawo autorskie są dwie międzynarodowe konwencje - Konwencja paryska z 1883 r. o ochronie własności przemysłowej ${ }^{12}$ oraz Konwencja berneńska z 1886 r. o ochronie dzieł literackich i artystycznych ${ }^{13}$. Przy czym jednocześnie, wskazać należy, że nie zawsze możliwe jest jednoznaczne rozdzielenie tych dwóch kategorii praw własności intelektualnej ${ }^{14}$.

Zgodnie z art. 1 ust. 3 Konwencji paryskiej o ochronie własności przemysłowej „własność przemysłowa” rozumiana jest $w$ najszerszym znaczeniu i stosuje się nie tylko do przemystu i handlu w ścistym znaczeniu, ale również do przemysłów rolnych $i$ wydobywczych oraz do wszystkich produktów wytworzonych lub naturalnych, jak na przykład: win, nasion, liści tytoniu, owoców, zwierząt, minerałów, wód mineralnych, piwa, kwiatów, mąki.

Zgodnie zaś z art. 2 Konwencji berneńskiej o ochronie dzieł literackich i artystycznych wyrazy „, dzieła literackie $i$ artystyczne” obejmuja wszelkie utwory literackie, naukowe i artystyczne, bez względu na sposób lub formę ich wyrażenia, jako to: książki, broszury i inne pisma; odczyty, przemówienia, kazania i inne dzieła tego samego rodzaju; dzieła dramatyczne lub dramatyczno-muzyczne; dzieła choreograficzne i pantomimy, których układ sceniczny zostat ustalony na piśmie lub $w$ inny sposób; utwory muzyczne ze słowami lub bez słów; utwory rysunkowe, malarskie, architektoniczne, rzeźby, utwory rytownicze i litograficzne; ilustracje, mapy geograficzne; plany, szkice i wyroby plastyczne, dotyczace geografji, topografji, architektury lub nauk. Wraz z postępem technologii reprograficznej ochrona udzielana przez prawo autorskie została rozszerzona na rysunki techniczne, dzieła trójwymiarowe,

\footnotetext{
10 M. Blakeney, Trends in Intellectual Property..., op. cit., s. 8; K. Czub, Prawo własności intelektualnej. Zarys wykładu, Warszawa 2016, s. 22, czy też R. Skubisz, Własność przemysłowa..., op. cit., s. 54.

11 J. Kępiński, A. Niewęgłowski, E. Nowińska, P. Podrecki, Pojęcie własności przemysłowej, (w:) Prawo własności przemysłowej. System prawa handlowego. t. 3, E. Nowińska, K. Szczepanowska-Kozłowska (red.), Warszawa 2015, s. 9.

Dz.U. z 1932 r., nr 2, poz. 8.

Dz.U. z 1935 r., nr 84, poz. 515.

Tak też A. Szewc, G. Jyż, Prawo własności przemysłowej, Warszawa 2011, s. 2.
} 
fotografie i dzieła kinematograficzne, a także na programy komputerowe, strony internetowe i bazy danych ${ }^{15}$.

Pojęcie „zasobów genetycznych” zdefiniowane jest przede wszystkim w art. 2 Konwencji o różnorodności biologicznej ${ }^{16}$, który wskazuje, że „zasoby genetyczne" oznaczają materiał genetyczny posiadający faktyczną lub potencjalną wartość. Ten sam przepis precyzuje też pojęcie „materiału genetycznego”, wskazując, że oznacza on jakikolwiek materiał roślinny, zwierzęcy, mikrobiologiczny lub innego pochodzenia, zawierający funkcjonalne jednostki dziedziczności.

Zważywszy, że rozważania podjęte niniejszym artykułem ograniczać się będą wyłącznie do genetycznych zasobów roślinnych, konieczne jest także przywołanie definicji legalnej „zasobów genetycznych roślin dla celów wyżywienia i rolnictwa”, którą zawiera art. 2 Międzynarodowego traktatu o zasobach genetycznych roślin dla wyżywienia i rolnictwa, przyjęty w Rzymie w dniu 3 listopada 2001 r. ${ }^{17}$ Zgodnie z tą definicją, ,zasoby genetyczne roślin dla celów wyżywienia i rolnictwa” oznaczają każdy materiał genetyczny pochodzenia roślinnego o faktycznej lub potencjalnej wartości dla celów wyżywienia i rolnictwa. Samo zaś pojęcie „,materiału genetycznego" jest ujmowane tą Konwencją jako każdy materiał pochodzenia roślinnego, w tym materiał służący do rozmnażania generatywnego i wegetatywnego, zawierający funkcjonalne jednostki dziedziczenia.

Warto także zwrócić uwagę na treść art. 2 pkt 2.1. a) załącznika do Rezolucji 8/83 przyjętej na XXII Sesji FAO, która miała miejsce w Rzymie w dniach 5-23 listopada 1983 r., ${ }^{18}$ zgodnie z którym ,genetyczne zasoby roślinne” oznaczają reprodukcyjny lub wegetatywny materiał rozmnożeniowy następujących kategorii roślin: 1) odmiany uprawne (odmiany) w aktualnym użyciu i nowo opracowane, 2) przestarzałe odmiany, 3) prymitywne odmiany (rasy lądowe), 4) gatunki dzikie i chwasty, zbliżone do odmian uprawnych, oraz 5) specjalne zasoby genetyczne (w tym linie elitarne, materiały hodowlane i mutanty).

Pojęcie „zasobów genetycznych”, a w szczególności „roślinnych zasobów genetycznych" nie jest zatem jednoznaczne. Na potrzeby niniejszego opracowania

M. Blakeney, Trends in Intellectual Property..., op. cit., s. 8.

16 Konwencja o różnorodności biologicznej weszła w życie 29 grudnia 1993 roku. Obecnie liczy 196 członków, w tym Polskę (która ratyfikowała Konwencję w 1996 roku - tekst jedn. Dz.U. z 2002 r., nr 184, poz. 1532) oraz Unię Europejską (która przyjęła Konwencję Decyzją Rady (EWG) z dnia 25 października 1993 roku - Dz.U. L 309 z dnia 13 grudnia 1993 roku, s. 1-20). Do Konwencji o różnorodności biologicznej zostały przyjęte dwa protokoły, uszczegóławiające jej postanowienia: w odniesieniu do transgranicznego przemieszczania żywych zmodyfikowanych genetycznie organizmów - Protokół Kartageński o bezpieczeństwie biologicznym do Konwencji o różnorodności biologicznej - przyjęty w dniu 29 stycznia 2000 roku w Montrealu, ratyfikowany przez Polskę w 2003 roku (Dz.U. z 2004 r. nr 216, poz. 2201), oraz w odniesieniu do dzielenia się korzyściami z wykorzystania zasobów genetycznych - Protokół z Nagoi do Konwencji o różnorodności biologicznej dotyczący dostępu do zasobów genetycznych oraz uczciwego i sprawiedliwego podziału korzyści wynikających z ich wykorzystania przyjęty w dniu 29 października 2010 roku w Nagoi, podpisany przez Polskę 20 września 2011 roku.

18 http://www.fao.org/wiews-archive/docs/Resolution_8_83.pdf. 
przyjęte jednak zostanie, że pod pojęciem „,roślinnych zasobów genetycznych” rozumieć należy każdy materiał genetyczny pochodzenia roślinnego, w szczególności służący do jego rozmnażania.

Niniejszy artykuł stanowi próbę syntetycznego wskazania tych spośród praw własności intelektualnej, które mogą służyć ochronie prawnej roślinnych zasobów genetycznych. Wydaje się, że zasadnicze znaczenie odgrywają w tym przypadku: sui generis wyłączne prawo do odmian roślin, patenty oraz przepisy dotyczące ochrony przed nieuczciwą konkurencją. Zasygnalizować należy także możliwość uzyskania pewnego stopnia ochrony roślinnych zasobów genetycznych z wykorzystaniem przepisów dotyczących ochrony oznaczeń geograficznych oraz znaków towarowych, jednak ze względu na ramy niniejszego opracowania, możliwości te zostaną jedynie w tym miejscu zasygnalizowane.

Ponadto, przedmiot rozważań stanowił będzie też problem, czy monopolizacja roślinnych zasobów genetycznych w ramach praw własności intelektualnej nie prowadzi do zagrożenia bezpieczeństwa żywnościowego.

\section{Sui generis wyłączne prawo do odmian roślin}

Niewątpliwie podstawowym prawem własności intelektualnej, obejmującym ochroną roślinne zasoby genetyczne, jest sui generis wyłączne prawo do odmian roślin. Funkcjonuje ono w oparciu o trzy grupy przepisów: 1) międzynarodowe, 2) wspólnotowe oraz 3) krajowe.

Międzynarodową podstawę ochrony prawnej nowych odmian roślin stanowią przepisy Konwencji o ochronie nowych odmian roślin ${ }^{19}$. Na mocy jej przepisów każda z umawiających się stron zobowiązana jest do udzielenia i ochrony praw hodowców. Hodowcą zaś jest: 1) osoba, która wytworzyła lub odkryła odmianę, 2) osoba, która jest pracodawcą lub zleceniodawcą wyżej wymienionej osoby, jeżeli przewiduje tak ustawodawstwo odnośnej umawiającej się strony oraz 3) prawny następca ww. podmiotów.

Przedmiotem ochrony zgodnie z Konwencją są odmiany roślin zdefiniowane jako zbiorowość roślin w obrębie jednego taksonu botanicznego najniższego znanego stopnia, która, niezależnie od tego, czy w pełni odpowiada warunkom udzielenia prawa hodowcy, może być: 1) określona przejawem właściwości wynikających z określonego genotypu lub kombinacji genotypów, 2) odróżniona od każdej innej

19 Międzynarodowa konwencja ochrony nowych odmian roślin zawarta w Paryżu w dniu 2 grudnia 1961 r. była następnie rewidowana w Genewie 10 listopada 1972 r., 23 października 1978 r. oraz 19 marca 1991 r. Powszechnie używa się na jej określenie nazwy Konwencja UPOV, która pochodzi od powstałego na podstawie konwencji Związku Ochrony Nowych Odmian Roślin (franc. Union pour la Protection des Obtentions Végétales) - tekst konwencji dostępny jest na stronie: http://www.upov.int/upovlex/en/conventions/1978/act 1978.html. 
zbiorowości roślin przejawem co najmniej jednej wyżej wymienionej właściwości i 3) właściwości te nie zmieniają się po rozmnożeniu.

Zakres podmiotowy i przedmiotowy sui generis wyłącznego prawa do odmian roślin definiowany jest w niemal tożsamy sposób także na gruncie prawa Unii Europejskiej oraz na gruncie ustaw krajowych sygnatariuszy Konwencji UPOV, w tym Polski. Zgodnie z art. 11 ust. 1 Rozporządzenia Rady (WE) nr 2100/94 z dnia 27 lipca 1994 r. w sprawie wspólnotowego systemu ochrony odmian roślin ${ }^{20}$, hodowcą jest osoba, która wyhodowała lub odkryła i rozwinęła odmianę, lub jej następca prawny. Ponadto, jeżeli hodowca jest pracownikiem, prawo do wspólnotowej ochrony odmian roślin określa prawo krajowe właściwe dla stosunku pracy, w ramach którego wyhodowano lub odkryto i rozwinięto odmianę. Art. 2 ust. 2 Rozporządzenia nr 2100/94 definiuje zaś pojęcie odmiany w sposób w zasadzie tożsamy z przyjętym Konwencją UPOV.

Obecnie problematyka ochrony prawnej odmian roślin w polskim prawie krajowym objęta jest ustawą z dnia 26 czerwca 2003 r. o ochronie prawnej odmian roślin ${ }^{21}$. W art. 2 pkt 7 tejże ustawy zdefiniowano pojęcie hodowcy jako osoby, która: 1) wyhodowała albo odkryła i wyprowadziła odmianę, albo 2) jest lub była pracodawcą osoby, o której wyżej mowa, albo zawarła umowę, w ramach której inna strona tej umowy wyhodowała albo odkryła i wyprowadziła odmianę, albo 3) jest następcą prawnym osób, o których mowa w pkt 1 i 2 . Definicja legalna odmiany jest zaś tożsama z przyjętą w Konwencji UPOV oraz w Rozporządzeniu nr 2100/94.

Nie wszystkie odmiany roślin definiowane w opisany wyżej sposób podlegają jednak ochronie sui generis wyłącznego prawa do odmian roślin. Dla uzyskania takiej ochrony konieczne jest bowiem, by odmiana spełniała określone przepisami przesłanki. Zgodnie z przepisami art. 5 ust. 1 Konwencji UPOV, art. 6 Rozporządzenia nr 2100/94 oraz art. 4 ust. 1 ustawy o ochronie prawnej odmian roślin, wyłączne prawo do odmiany może być przyznane jedynie wówczas, gdy odmiana jest: 1) odrębna, 2) wyrównana, 3) trwała oraz 4) nowa. Przesłanki te oznaczone zostały w regulacji międzynarodowej, wspólnotowej i krajowej w sposób niemal tożsamy. Najogólniej rzecz ujmując, odmiana jest odrębna, jeżeli w dniu złożenia wniosku o przyznanie wyłącznego prawa różni się ona w sposób wyraźny co najmniej jedną właściwością od innej odmiany powszechnie znanej22. Jest ona wyrównana, jeżeli, przy uwzględnieniu sposobu rozmnażania właściwego dla tej odmiany, jest ona wystarczająco jednolita pod względem właściwości branych pod uwagę przy bada-

20 Dz. Urz. UE L 1994 r., nr 227, s. 1.

21 Tekst jedn. Dz.U. z 2018 r., poz. 432.

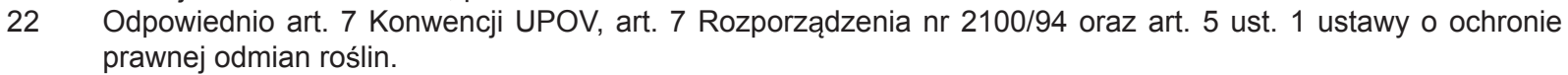


niach odrębności, jak również innych właściwości użytych do opisu tej odmiany ${ }^{23}$. Odmianę uznaje się zaś za trwałą, jeżeli jej charakterystyczne właściwości uwzględnione przy badaniu jej odrębności, jak też inne właściwości użyte do opisu tej odmiany nie zmieniają się po jej rozmnożeniu ${ }^{24}$. Przesłanka nowości jest zaś spełniona wówczas, gdy w dniu złożenia wniosku o udzielenie prawa hodowcy, materiał do rozmnożenia lub materiał ze zbioru odmiany nie był sprzedany lub w inny sposób przekazany przez hodowcę lub za jego zgodą osobom trzecim w celu wykorzystania odmiany: 1) na obszarze umawiającej się strony, w której złożono wniosek, nie wcześniej niż jeden rok przed tym dniem 2) na obszarze innym niż umawiającej się strony, w której złożono wniosek, nie wcześniej niż cztery lata, a w przypadku drzew i winorośli nie wcześniej niż sześć lat, przed wyżej wymienionym dniem.

Podkreślić zatem należy, że niewątpliwie definicja odmiany ukształtowana w przepisach dotyczących sui generis wyłącznego prawa do odmian roślin obejmuje również roślinne zasoby genetyczne rozumiane jako każdy materiał genetyczny pochodzenia roślinnego, w szczególności służący do jego rozmnażania. Tym samym, regulacje prawne, dotyczące czy to krajowego, czy też wspólnotowego wyłącznego prawa do odmian roślin mają pośrednio za swój przedmiot także roślinne zasoby genetyczne. Zważywszy jednak, że ochrona, jaką gwarantuje wyłączne prawo do odmian roślin, zależna jest od spełnienia przez konkretną odmianę przesłanek jej ochrony, nie wszystkie roślinne materiały genetyczne znajdą ochronę prawa hodowcy. Ochrony takiej pozbawione będą w szczególności zasoby genetyczne nieodznaczające się przymiotem nowości.

\section{Patenty}

Patentem, zgodnie z terminologią tradycyjnie ustaloną i obowiązującą we współczesnych porządkach prawnych, określa się podmiotowe prawo, którego treścią jest terytorialnie i czasowo ograniczona wyłączność gospodarczej eksploatacji wynalazku, czyli szczególnego rodzaju przedmiotu niematerialnego ${ }^{25}$. Prawo to powstaje na mocy decyzji mającej charakter konstytutywny, wydanej przez wyspecjalizowany organ administracji rządowej - urząd patentowy ${ }^{26}$.

Kluczową kwestią związaną z patentowaniem zasobów genetycznych, w tym roślinnych zasobów genetycznych, jest to, czy sekwencję DNA można scharakteryzować jako ,wynalazek”. We wczesnej historii prawa patentowego uważano, że wy-

23 Odpowiednio art. 8 Konwencji UPOV, art. 8 Rozporządzenia nr 2100/94 oraz art. 6 ustawy o ochronie prawnej odmian roślin.

24 Odpowiednio art. 9 Konwencji UPOV, art. 9 Rozporządzenia nr 2100/94 oraz art. 7 ustawy o ochronie prawnej odmian roślin.

25 A. Szajkowski, H. Żakowska-Henzler, Patent, (w:) System Prawa Prywatnego. Tom 14A. Prawo własności przemysłowej, Warszawa 2017, s. 624.

26 Ibidem, s. 624. 
nalazek wiąże się z jakimś rodzajem innowacji technicznych ${ }^{27}$ i rozróżnia się wynalazki podlegające opatentowaniu i odkrycia niepodlegające patentowi ${ }^{28}$.

Wymóg technicznego charakteru wynalazku sprawiał, że uznawano wówczas, iż wynalazek musiał być przeznaczony do stosowania w przemyśle ${ }^{29}$, co wyłączało możliwość jego zastosowania np. w rolnictwie czy też hodowli roślin lub zwierząt. Wraz z upływem czasu pojęcie wynalazku uległo rozciągnięciu także na inne dziedziny gospodarki, w tym na rolnictwo. Przy czym za oznakę technicznego charakteru takich wynalazków uznawano to, że dotyczą one materii nieożywionej ${ }^{30}$. Obecnie za wyznacznik technicznego charakteru wynalazku uznaje się to, że stanowi on nowy sposób wykorzystania materii nieożywionej lub ożywionej w celu zaspokojenia potrzeb człowieka ${ }^{31}$. Koncepcja ta znalazła odzwierciedlenie np. w wyroku Sądu Najwyższego USA w sprawie Diamond v Chakrabarty ${ }^{32}$, który orzekł, że bakteria zmodyfikowana genetycznie w celu degradacji ropy naftowej była wynalazkiem.

Tradycyjnie prawo własności przemysłowej zabraniało patentowania odkryć33. Pojawienie się jednak koncepcji wynalazku biotechnologicznego spowodowało konieczność modyfikacji koncepcji odkrycia. Z racji charakteru niniejszego opracowania nie sposób przedstawić w tym miejscu ewolucji poglądów dotyczących koncepcji odkrycia pod wpływem osiągnięć biotechnologii. Konieczne jest jednak wskazanie, że podstawą do przyznania takim osiągnięciom zdolności patentowej jest odmienność materiału biologicznego występującego w naturze (przedmiotu odkrycia) od materiału biologicznego, po wyizolowaniu z naturalnego środowiska, który może być uznany za przedmiot wynalazku.

Jakkolwiek zatem Konwencja o patencie europejskim ${ }^{34}$ w art. 53 lit. b) wyraźnie wyklucza możliwość patentowania odmian roślin albo ras zwierzą lub czysto biologicznych sposobów hodowli roślin lub zwierząt, to jednak przepis ten nie ma zastosowania do sposobów mikrobiologicznych ani produktów otrzymywanych tymi sposobami. Przy czym zgodnie z zasadą 23b pkt 5 tejże Konwencji sposób produkcji roślin lub zwierząt jest czysto biologicznym sposobem, jeśli w całości składa się ze zjawiska naturalnego, takiego jak krzyżowanie lub selekcjonowanie.

J. Kępiński, A. Niewęgłowski, E. Nowińska, P. Podrecki, Pojęcie własności przemysłowej..., op. cit., s. 105. 447 U.S. 303 (1980), https://trp.utoronto.ca/students/wp-content/uploads/sites/2/2016/10/DIAMOND-v-Chackabarty.pdf.

33 A. Szajkowski, H. Żakowska-Henzler, Patent..., op. cit., s. 386.

34 Konwencja o udzielaniu patentów europejskich (Konwencja o patencie europejskim), sporządzona w Monachium dnia 5 października 1973 r., zmieniona aktem zmieniającym artykuł 63 Konwencji z dnia 17 grudnia 1991 r. oraz decyzjami Rady Administracyjnej Europejskiej Organizacji Patentowej z dnia 21 grudnia 1978 r., 13 grudnia 1994 r., 20 października 1995 r., 05 grudnia 1996 r. oraz 10 grudnia 1998 r. wraz z Protokołami stanowiącymi jej integralną część (Dz.U. z 2004 r., nr 79, poz. 737). 
Stanowisko to znajduje potwierdzenie w treści Dyrektywy 98/44/WE Parlamentu Europejskiego i Rady z dnia 6 lipca 1998 r. w sprawie ochrony prawnej wynalazków biotechnologicznych ${ }^{35}$. Zgodnie z jej art. 3 ust. 1 dla celów dyrektywy zdolność patentowq majq wynalazki, które sq nowe, posiadaja poziom wynalazczy i nadaja się do przemystowego stosowania, nawet jeśli dotyczq produktu składajqcego się lub zawierajacego materiat biologiczny lub sposobu, za pomocq którego materiat biologiczny jest produkowany, przetwarzany lub wykorzystywany.

Przy czym, zgodnie z art. 3 ust. 2 Dyrektywy przedmiotem wynalazku może być materiał biologiczny, który jest wyizolowany ze swojego naturalnego środowiska lub wyprodukowany przy pomocy sposobu technicznego, nawet jeśli poprzednio występowat w naturze.

Dyrektywa ta otwiera także drzwi do patentowania odmian roślin, ponieważ jej art. 4 ust. 2 stanowi, że wynalazki dotyczqce roślin lub zwierzq̨ podlegajq opatentowaniu, jeżeli techniczna wykonalność wynalazku nie ogranicza się do konkretnej odmiany roślin lub zwierzq̨t.

Niewątpliwie zatem, roślinne zasoby genetyczne mogą być również przedmiotem patentów.

\section{Przepisy dotyczące ochrony przed nieuczciwą konkurencją}

Współcześnie w doktrynie prawa konkurencji dominuje pogląd, że zapewnienie efektywnej ochrony w tej dziedzinie prawa powinno służyć: 1) ochronie interesów przedsiębiorców (konkurentów), obejmujących swobodę podejmowania i prowadzenia działalności gospodarczej; 2) ochronie interesów klientów (w tym konsumentów) do podejmowania świadomych i suwerennych decyzji rynkowych oraz 3) ochronie interesu publicznego (ogółu, całego społeczeństwa) do respektowania podstawowych zasad uczciwej, niezafałszowanej gry rynkowej ${ }^{36}$. Spośród zakreślonych w ten sposób celów prawa konkurencji, cel pierwszy - ochrona interesów przedsiębiorców, może obejmować swoim zakresem także ochronę roślinnych zasobów genetycznych jako tajemnicy przedsiębiorstwa.

W polskiej regulacji prawnej definicję tajemnicy przedsiębiorstwa zawiera art. 11 ust. 2 ustawy z dnia 16 kwietnia 1993 r. o zwalczaniu nieuczciwej konkurencji ${ }^{37}$. Zgodnie $\mathrm{z}$ tym przepisem przez tajemnice przedsiębiorstwa rozumie się informacje techniczne, technologiczne, organizacyjne przedsiębiorstwa lub inne informacje posiadajqce wartość gospodarczq, które jako catość lub w szczególnym zestawieniu i zbiorze ich elementów nie sq powszechnie znane osobom zwykle zaj-

\footnotetext{
35 Dz. Urz. UE L 213, 30.07.1998 r., s. 13-21.

36 A. Tischner, Cele i zakres zastosowania ZNKU, (w:) System Prawa Prywatnego. Tom 15. Prawo konkurencji, M. Kępiński (red.), Warszawa 2014, s. 90.

37 Tekst jedn. Dz.U. z 2018 r., poz. 419.
} 
mującym się tym rodzajem informacji albo nie sa łatwo dostępne dla takich osób, o ile uprawniony do korzystania z informacji lub rozporządzania nimi podjąt, przy zachowaniu należytej staranności, działania w celu utrzymania ich $w$ poufności.

Warto podkreślić, że pośród licznych koncepcji przedmiotu ochrony regulacji art. 11 ustawy o zwalczaniu nieuczciwej konkurencji ${ }^{38}$ można wskazać również tę, która podkreśla, iż objęte tajemnicą informacje można postrzegać jako ochronę szczególnego rodzaju dobra niematerialnego ${ }^{39}$.

Nie ulega wątpliwości, że roślinne materiały genetyczne są nośnikami informacji mogących stanowić tajemnicę przedsiębiorstwa. Zwłaszcza przedsiębiorstwa zajmującego się twórczą hodowlą nowych odmian roślin. Wytwarzając materiały hodowlane służące jako źródło danych genetycznych dla przyszłych odmian, przed osiągnięciem przez te materiały cech pozwalających na uzyskanie ochrony wyłącznego prawa, hodowcy starają się zachować takie materiały wyjściowe w pełnej poufności. Służą temu zarówno wewnętrzne regulacje z zakresu prawa pracy, jak też instrumenty organizacyjne i techniczne dotyczące zabezpieczenia informacji poufnych, takie jak np. kodowanie materiałów hodowlanych na polach doświadczalnych.

Warto zatem wskazać, że przepisy ustawy o zwalczaniu nieuczciwej konkurencji, w art. 23 sankcjonują naruszenie tajemnicy przedsiębiorstwa odpowiedzialnością karną. Zbliżone rozwiązania stosowane są także w innych krajach.

W wyroku w sprawie Franklin przeciwko Giddins ${ }^{40}$, Sąd Najwyższy Queensland zajmował się kradzieżą przez oskarżonego sadzonek z sadu pokrzywdzonych, co umożliwiło oskarżonemu po szczepieniu uprawę pewnej odmiany nektaryny, dla celów konkurencyjnych w stosunku do pokrzywdzonych. Sąd uznał takie działanie za naruszenie (kradzież) poufnych informacji zawartych w składzie genetycznym pąka nektaryny.

W sprawie Pioneer Hi-Bred Int'l przeciwko Holden Found Seeds ${ }^{41}$, VIII Sąd Apelacyjny Stanów Zjednoczonych stwierdził, że pozwany opracował materiał siewny z przywłaszczonego materiału genetycznego, który stanowił tajemnicę handlową przedsiębiorstwa powoda.

Również w Polsce toczy się obecnie przed Sądem Okręgowym w Poznaniu precedensowe postępowanie karne, którego przedmiotem jest naruszenie tajemnicy przedsiębiorstwa hodowlanego poprzez zabór oraz wykorzystanie we własnej dzia-

38 E. Wojcieszko-Gałuszko, Ochrona prawna know-how w prawie polskim na tle prawnoporównawczym, Kraków 2002, s. 146 i n.

39 S. Sołtysiński, S. Gogulski, Czyny nieuczciwej konkurencji, (w:) Ustawa o zwalczaniu nieuczciwej konkurencji. Komentarz, Warszawa 2019, Nb 19, czy też H. Köhler, (w:) H. Köhler, J. Bornkamm, UWG, 2012, Nb 2.

40 W sprawie (1978) Qd R 72, http://achristie.com/wp-content/uploads/2016/06/Franklin-v-Giddens-QSC-1978.pdf.

41 W sprawie 35 F.3d 1226 (8th Cir. 1994), https://law.resource.org/pub/us/case/reporter/ F3/035/35.F3d.1226.923556.92-3292.html. 
łalności gospodarczej materiałów hodowlanych nieujawnionych do publicznej wiadomości.

Nie ulega zatem wątpliwości, że roślinne zasoby genetyczne mogą stanowić także przedmiot ochrony w ramach przepisów dotyczących ochrony przed nieuczciwą konkurencją.

\section{Wnioski}

Jak wskazuje się $\mathrm{w}$ doktrynie ${ }^{42}$, zastosowanie praw własności intelektualnej do roślinnych zasobów genetycznych stało się w ciągu ostatnich piętnastu lat wyraźną cechą innowacji w rolnictwie. $\mathrm{Z}$ jednej strony, umożliwia to stymulowanie twórczych prac zmierzających do hodowli nowych odmian roślin, budowanie banków genowych oraz poszerzanie różnorodności biologicznej. $Z$ drugiej strony budzi także obawy o charakterze etycznym, wynikające z tego, że prawa własności intelektualnej do roślinnych zasobów genowych, podobnie jak i inne prawa własności intelektualnej, coraz częściej koncentrowane są w niewielkiej liczbie dużych, globalnych przedsiębiorstw. Może to oznaczać w praktyce ograniczenia w dostępie do postępu biologicznego przez osoby najuboższe oraz w dłuższej perspektywie czasu hamować rozwój nowych produktów i negatywnie wpływać na bezpieczeństwo żywnościowe.

Zadaniem prawa jest poszukiwanie instrumentów służących przeciwdziałaniu opisanym wyżej negatywnym tendencjom, przy jednoczesnym poszanowaniu praw twórców nowych dóbr intelektualnych. Wydaje się, że pośród praw własności intelektualnej wykorzystywanych w ochronie roślinnych zasobów genetycznych, to sui generis wyłączne prawo do odmian roślin, w najwyższym stopniu równoważy interesy podmiotów uprawnionych z tytułu wyłącznego prawa do odmian roślin z interesami społeczeństwa. Ma to miejsce dzięki mechanizmom ograniczającym prawo hodowców, takim jak: przywilej hodowcy, odstępstwo rolne, czy też uprawnienie do korzystania z materiału siewnego odmian roślin objętych wyłącznym prawem do własnych, niezarobkowych celów.

Nie należy także pomijać postanowień art. 30 porozumienia TRIPS, który stanowi, że członkowie (porozumienia) mogq dokonać ograniczonych wytaczeń od praw wytacznych przyznanych patentem, pod warunkiem, że takie wytaczenia nie sq bezzasadnie sprzeczne z normalnym wykorzystaniem patentu i nie naruszajq bezzasadnie prawnie uzasadnionych interesów wtaściciela patentu oraz biorq pod uwage prawnie uzasadnione interesy stron trzecich.

W ten sposób także prawo patentowe może pozwolić na prowadzenie badań i hodowli w trakcie okresu patentowego, a rolnikom można przyznać prawo do za- 
chowywania i ponownego wykorzystywania nasion we własnych gospodarstwach w przypadku odmian roślin lub niektórych składników tych odmian podlegających ochronie patentowej, w sposób podobny do odstępstwa rolnego w ramach sui generis wyłącznego prawa do odmiany.

Na koniec wreszcie wskazać należy, że z samej istoty ochrony roślinnych zasobów genetycznych wynika to, iż w znacznym zakresie dotyczy ona dóbr niematerialnych, co do których możemy odnieść przymiot nowości w takim czy innym kształcie. Tym samym w domenie publicznej pozostaje cały szereg materiałów genetycznych, które nie są i nie mogą być objęte taką ochroną. 


\section{PLANT GENETIC RESOURCES AS AN OBJECT OF INTELLECTUAL PROPERTY RIGHTS}

Keywords: intellectual property rights, genetic resources, legal protection of plant varieties, biotechnology

Extension of the scope of the application of contemporary intellectual property rights for the newer objects under protection is a noticeable trend. Plant genetic resources are gaining more and more protection among the new intellectual property which is the object of rights to intangible assets.

The concept of plant genetic resources has been defined in a number of international instruments such as the Convention on Biological Diversity, or the International Treaty on Plant Genetic Resources for Food and Agriculture. In the general context the term 'plant genetic resources' relates to any genetic material of plant, in particular applied for its propagation.

The characteristic feature of plant genetic resources thus defined is that they are subject not only to one form of protection of intangible property, but they could find protection based on the rules pertaining to the exclusive right of plant varieties, patents, or the rights protecting from unfair competition.

Such wide protection of plant genetic resources can pose controversies towards developing biotechnological monopolies concerning maintenance of food security. However, the role of legal regulations is searching for a balance between the need to support implementation of modern technologies relating to development of genetic resources and the respect to interests of society.

Bibliografia:

Blakeney M., Trends in Intellectual Property Rights relating to genetic resources for food and agriculture, FAO 2011, Background Study Paper No 58.

Czub K., Prawo własności intelektualnej. Zarys wykładu, Warszawa 2016.

Jänich V., Geistiges Eigentum: eine Komplementärerscheinung zum Sacheigentum?, Mohr Siebeck 2002.

Kępiński J., Niewęgłowski A., Nowińska E., Podrecki P., Pojęcie własności przemysłowej, (w:) Prawo własności przemysłowej. System prawa handlowego. Tom 3, E. Nowińska, K. Szczepanowska-Kozłowska (red.), Warszawa 2015.

Ponikło A., Gutowski J., Polskie prawo patentowe. Komentarz, Warszawa 1935.

Skubisz R., Własność przemysłowa w systemie prawa, (w:) System Prawa Prywatnego, t. 14A, Prawo własności przemysłowej, R. Skubisz (red.), Warszawa 2012. 


\section{Paweł Gała}

Sołtysiński S., Gogulski S., Czyny nieuczciwej konkurencji, (w:) Ustawa o zwalczaniu nieuczciwej konkurencji. Komentarz, Warszawa 2019.

Szajkowski A., Żakowska-Henzler H., Patent, (w:) System Prawa Prywatnego, t. 14A. Prawo własności przemysłowej, Warszawa 2017.

Szewc A., Jyż G., Prawo własności przemysłowej, Warszawa 2011.

Tischner A., Cele i zakres zastosowania ZNKU, (w:) System Prawa Prywatnego, t. 15. Prawo konkurencji, M. Kępiński (red.), Warszawa 2014.

Wojcieszko-Gałuszko E., Ochrona prawna know-how w prawie polskim na tle prawnoporównawczym, Kraków 2002. 